\title{
Peningkatan Produksi Dan Perbaikan Manajemen Ukm Kue Pudak Di Kelurahan Lumpur Gresik
}

\author{
Astria Hindratmo ${ }^{1}$, Ong Andre Wahyu Riyanto ${ }^{2}$, Dyah Puspita Indah Budi Sari Wulan ${ }^{3}$ \\ ${ }^{1}$ Universitas Wijaya Putra Surabaya \\ ${ }^{2}$ Universitas Wijaya Putra Surabaya \\ ${ }^{3}$ Universitas Wijaya Putra Surabaya
}

astriahindratmo@uwp.ac.id, ongandre@uwp.ac.id, dyahpuspitaibsw1998@gmail.com

\begin{abstract}
Abstrak
UKM Kue Pudak Kelurahan Lumpur Kecamatan Lumpur merupakan salah satu lokasi penjualan kue pudak yang terkenal di Gresik. UKM tersebut berproduksi selama puluhan tahun. Pemasalahan produksi tidak adanya proses yang menggunakan mesin Teknologi Tepat Guna (TTG) sehingga waktu proses produksi kurang efisien terutama pada proses pengadukan bahan baku menjadi adonan. Produk masih belum memiliki variasi ukuran isi yang sesuai selera konsumen. Pada aspek manajemen yaitu manajemen pemasaran yang masih belum terkonsep dengan baik sehingga belum memetakan segmentasi, taget, dan posisi produk terhadap produk pesaing. Terkait manajemen mutu dimana saat ini mitra belum sepenuhnya memperhatikan mutu produk dari segi higienis. Tujuan dari kegiatan ini yaitu untuk membantu mitra UKM dapat meningkatkan produktivitas dan meningkatkan penjualan produk dengan perbaikan manajemen pemasaran dan mutu. Metode penyelesaian masalah mitra yaitu membantu merancang desain mesin TTG, pelatihan membuat variasi produk. Pelatihan merancang konsep marketing mix (Product, Price, Place, Promotion) dan Segmentasi, Target, Positioning (STP). Pelatihan produksi yang bersih dan membuat Standar Operation Procedure (SOP) produksi yang bersih agar mutu produk menjadi higienis. Hasilnya kegiatan menghasilkan desain mesin pengaduk, variasi ukuran produk, konsep marketing mix, dan menghasilkan SOP produksi yang bersih.
\end{abstract}

Kata Kunci : UKM, TTG, Marketing Mix, STP.

\section{PENDAHULUAN}

Kue Pudak Gresik merupakan salah satu oleh-oleh khas kota Gresik yang hanya di jual di Kota Gresik. Jumlah UKM kue Pudak Gresik cukup banyak di jumpai di kota Gresik. Hampir setiap wisatawan atau warga dari luar kota saat berkunjung ke kota Gresik selalu membeli kue pudak sebagai oleh-oleh. Oleh karena itu hampir setiap orang yang berkunjung selalu membeli oleh-oleh termasuk kue pudak. Dengan banyaknya pembeli maka pembuat dan penjual pudak masih tetap banyak jumlahnya hingga saat ini. Beberapa warga kota Gresik melihat peluang tersebut, maka banyak warga yang membuat kue pudak sebagai mata pencaharian utama mereka. Salah satu daerah yang sebagian warganya membuat kue pudak yaitu warga di sekitaran Jalan Sindujoyo Kota Gresik.

Kampung UKM kue Pudak Gresik terletak di sepanjang Jalan Sindujoyo Kota Grasik terletak di Kelurahan Lumpur Kecamatan Gresik Kabupaten Gresik dapat dikatakan merupakan daerah yang strategis dimana terletak di tengah kota Gresik. Keseharian sebagian besar warga daerah Sindujoyo yaitu pembuat kue pudak. Rata-rata semua pembuat kue pudak dari hasil usaha turun temurun yang sudah dilakukan sejak jaman orang tua mereka yang sekitar

Teknologi Tepat Guna 
puluhan tahun yang lalu. Kondisi saat ini para pengrajian sekitaran jalan Sindujoyo Gresik masih banyak yang berjualan dengan membuka toko di depan rumah mereka masing-masing.

Walaupun banyak yang menjual kue pudak di daerah jalan Sindujoyo dan juga selalu ada pesanan, namun pada kenyataannya secara perkembangan bisnis rata-rata UKM pembuat pudak menunjukkan perkembangan yang cukup lambat. Beberapa faktor yang menjadi permasalahan yang menyebabkan perkembangan bisnis cukup lambat yaitu (1) tidak mampu memenuhi permintaan pelanggan yang cukup banyak dikarena proses produksi dengan peralatan yang manual, (2) produk tidak memiliki variasi ukuran (3) penjualan hanya mengandalkan penjualan toko di depan rumah dan, (4) penerapan manajemen mutu yang kurang.

Permasalahan pertama mitra yaitu tidak mampu memenuhi permintaan pudak yang banyak dikarenakan proses pruduksi menggunakan peralatan yang sederhana mulai dari bak air dan centong untuk proses pengadukan adonan. Sehingga dalam proses produksi membutuhkan waktu proses yang cukup lama dan tenaga manusia cukup terkuras. Maka dari itu perlunya desain mesin untuk pengaduk yang ergonomis sehingga memudahkan pemakaian mesin serta meningkatkan kapasitas produksi. Sentuhan peralatan Teknologi Tepat Guna (TTG) yang ergonomis untuk UKM untuk saat ini sangatlah penting sebab akan memberikan rasa aman dan nyaman yang berdampak pada peningkatan produktivitas kerja (Nurmianto, 2018). Selain itu juga penggunaan alat TTG berfungsi untuk meningkatkan nilai tambah berdasarkan aspek ekonomi dan lingkungan hidup (Muhi, 2009).

Permasalahan kedua mitra yaitu mitra saat ini belum memiliki variasi produk. Produk yang dihasilkan saat ini hanya memiliki ukuran yang standar saja dan belum memiliki ukuran yang berbeda dari ukuran standarnya yaitu seperti ukuran yang lebih kecil ataupun yang lebih besar yang sesuai dengan segementasinya. Dimana variasi ukuran dapat disesuaikan konsumenya mulai dari anak-anak, remaja, hingga orang dewasa.

Permasalahan ketiga mitra yaitu saat ini mitra masih belum memiliki konsep pemasaran yang baik dimana penjualan hanya tergantung dari hasil penjulan di toko saja. Hal tersebut menyebabkan peningkatan penjualan cenderung melambat. Sehingga mitra perlu memiliki konsep pemasaran dengan menentukan Segmentasi, Targetting, Positioning (STP) dan rancangan konsep 4P (Product, Price, Place, Promotion). Menurut Kotler dan keller (2009) pemasaran adalah suatu proses untuk mendapatkan komunikasi serta memberi nilai pada pelanggan dengan maksud untuk keuntungan suatu organisasi. Maka dari itu, pemasaran yang terkonsep dengan baik memberikan pengaruh pada penjualan produk perusahaan. Kemudian juga strategi pemasaran yang optimal akan berpengaruh terhadap minat konsumen untuk membeli produk yang ditawarkan (Moniharapon et. al., 2015).

Permasalahan keempat mitra yaitu penerapan manajemen mutu yang kurang. Dalam proses produksi saat ini mitra UKM masih belum memperhatikan mutu produk dengan baik dimana hal tersebut terlihat mitra dalam proses pembuatan pudak, beberapa aktifitas tidak menjaga kebersihan seperti tidak pakai sarung tangan dan peralatan yang sudah dipakai tidak langsung dibersihkan. Akibat kurangnya tingkat kebersihan dapat menyebabkan mutu produk kurang higienis. Padahal menurut Wardana et. al. (2007) penerapan mutu yang baik bagi UKM akan meningkatkan loyalitas dan kepuasan pelanggan sehingga akan berdampak pada peningkatan omset penjualan. Maka dari itu mitra perlu memiliki Standart Operation Procedure (SOP) tentang proses produksi yang bersih dan produk agar higienis.

Tujuan dari kegiatan ini yaitu untuk meningkatkan produksi dan perbaikan manajemen. Pada peningkatan produksi bertujuan untuk meningkatkan produktivitas dan merancang variasi ukuran produk yang sesuai segmentasi. Sedangkan untuk perbaikan manajemen bertujuan untuk memperbaiki manajemen pemasaran agar penjualan meningkat dan memperbaiki mutu produk agar produk lebih higienis.

Rencana penyelesaian masalah yang ada pada mitra yaitu dengan merancang desain mesin pengaduk adonan untuk mempercepat proses produksi, dan memberi pelatihan perancangan variasi ukuran produk yang sesuai dengan segmentasi. Kemudian juga merancang konsep

$$
\text { Teknologi Tepat Guna }
$$


marketing dengan memberikan pelatihan perancangan konsep marketing mix dan menentukan segmentasi, targeting, positioning. Selain itu melakukan perbaikan manajemen mutu produk dengan memberikan pelatihan penggunaan peralatan yang bersih dan membuat standar operation procedure (SOP) untuk menjaga kebersihan dalam proses produksi.

Tabel 1. Penyelesaian Permasalahan

\begin{tabular}{|c|c|c|}
\hline No & Permasalahan & Solusi \\
\hline \multirow{2}{*}{1} & \multirow{2}{*}{ Produksi } & $\begin{array}{l}\text { Pemberian Teknologi Tepat } \\
\text { Guna (TTG) }\end{array}$ \\
\hline & & Pembuatan variasi Produk \\
\hline \multirow{2}{*}{2} & \multirow{2}{*}{ Manajemen } & $\begin{array}{l}\text { Perancangan konsep } \\
\text { marketing mix (4P) dan STP } \\
\text { (Segmentation, Targetting, } \\
\text { Positioning) }\end{array}$ \\
\hline & & $\begin{array}{l}\text { Pembuatan SOP (Standar } \\
\text { operation Prosedure) proses } \\
\text { produksi yang bersih }\end{array}$ \\
\hline
\end{tabular}

Teknologi Tepat Guna (TTG) menurut Slamet (1994) yaitu teknologi yang digunakan secara sesuai atau teknologi yang tepat penggunaannya yang telah dikembangkan dari yang tradisional, sederhana dan proses pengenalannya lebih banyak ditentukan berdasarkan keadaan lingkungan dan mata pencaharian masyarakat. Variasi produk menurut Kotler dan keller (2009) yaitu variasi produk sebagai ahli tersendiri dalam suatu merek atau lini produk yang dapat dibedakan berdasarkan ukuran, harga, penampilan atau ciri-ciri. Kemudian menurut Tjiptono (2008) yaitu suatu unit khusus dalam suatu merek atau lini produk yang dapat dibedakan berdasarkan ukuran, harga, penampilan, atau atribut lainnya. Biasanya disebut pula stock keeping unit atau variasi produk.

Marketing mix adalah suatu perangkat yang terdiri dari produk, harga, promosi dan distribusi, yang didalamnya akan menentukan tingkat keberhasilan pemasaran dan semua itu ditujukan untuk mendapatkan respon yang diinginkan dari pasar sasaran (Selang, 2013). Mutu diartikan sebagai kesesuaian dengan persyaratan pada setiap produk, jasa, atau proses yang sesuai dengan persyaratan- persyaratan pada produk atau jasa (Sriwidadi, 2001). Sehingga manajemen mutu yaitu suatu aktivitas pengelolaan mutu terhadap suatu produk.

Pengembangan metode penyelesaian masalah pada mitra yaitu dapat dikembangkan pada proses perancangan desain mesin (TTG) untuk menjadi suatu alat yang real digunakan untuk UKM. Kemudian pada penyelesaian pada perancangan marketing mix dapat dikembangkan menjadi metode pemasaran dengan cakupan area yang lebih luas.

\section{METODE}

Metode yang ada pada kegiatan penyelesaian masalah mitra UKM kue pudak Gresik yaitu dengan menggunakan kegiatan perancangan desain mesin pada proses produksi yaitu proses pengadukan adonan dan beberapa pelatihan. Kegiatan pertama (1) yaitu perancangan desain mesin atau perancangan TTG yang sesuai keinginan UKM pada aktivitas pengadukan adonan. Pada kegiatan ini mitra UKM di wawancara untuk mendapatkan atribut desain mesin pengaduk yang diinginkan, lalu dilakukan desain mesin pengaduk. Kegiatan kedua (2) yaitu memberikan pelatihan perancangan variasi produk berdasarkan ukuran isi pudak. Pada kegiatan ini mitra dilatih membuat produk dengan ukuran yang lebih kecil untuk menambah variasi produk. Kegiatan ketiga (3) yaitu pelatihan perancangan marketing mix dan Segmentation, Targetting, Positioning (STP). Pada kegitan ini mitra dilatih untuk membuat konsep pemasaran produk berdasarkan 4P (Product, Price, Place, Promotion) dan menentukan segmentasi, target, positioning. Kegiatan keempat (4) yaitu memberikan pelatihan pembuatan SOP (Standar operation Prosedure) produksi yang bersih dan pelatihan proses produksi dengan menggunakan peralatan untuk menjaga kebersihan agar produk lebih higienis.

\section{HASIL DAN PEMBAHASAN}

\section{Hasil Perancangan Desain Mesin Pengaduk}

Pada kegiatan perancangan desain mesin atau desain TTG pada proses pengadukan adonan. Kegiatan hasil dari wawancara dengan mitra pada pelaku UKM pudak. Hasil desain yang sesuai dengan 
keinginan mitra terkait mesin pengaduk pada gambar di bawah ini.

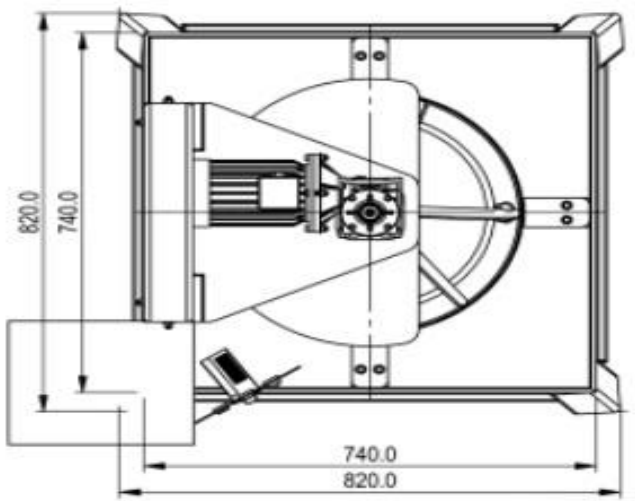

Gambar 1 Mesin Pengaduk Tampak Atas

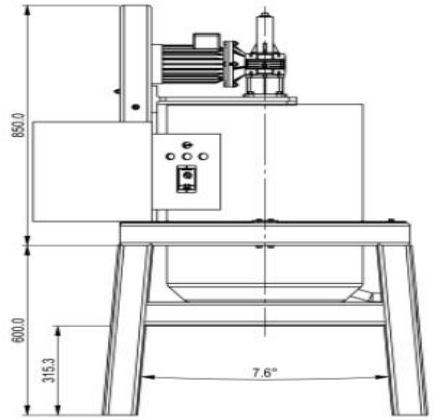

Gambar 2. Mesin Pengaduk Tampak Samping

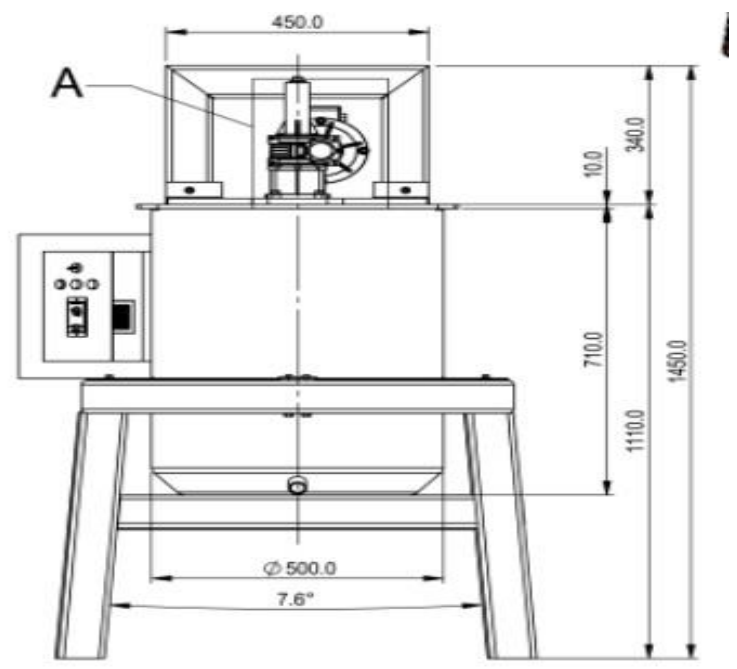

Gambar 3. Mesin Pengaduk Tampak Depan

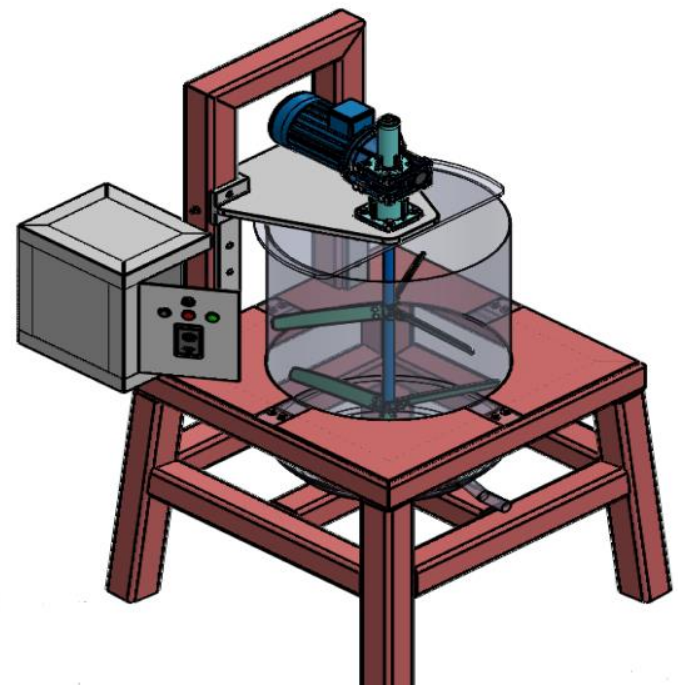

Gambar 4. Mesin Pengaduk Tampak 3D

\section{Hasil Perancangan Variasi Produk}

Perancangan variasi produk didapatkan dari hasil wawancara dengan beberapa pelanggan yang menginginkan adanya variasi ukuran terutama ukuran yang cocok untuk anak-anak. Dari hasil tersebut dilakukan pelatihan membuat produk dengan ukuran yang lebih kecil yaitu ukuran setengah dari ukuran standarnya.

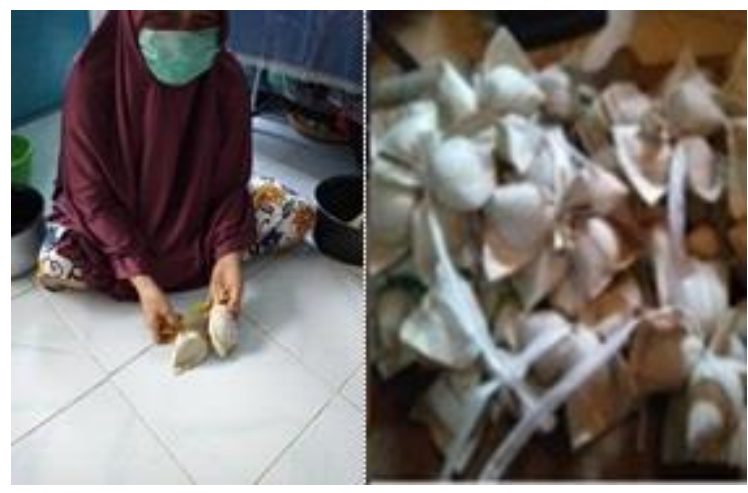

Gambar 5. Pelatihan Variasi Produk

\section{Hasil Pelatihan Perancangan Marketing Mix}

Perancangan konsep marketing mix dilakukan untuk menghasilkan suatu konsep untuk membuat strategi pemasaran yang lebih tepat sasaran. Pada pelatihan ini mitra UKM di latih menentukan 4P (Product, Price, Place, Promotion) dan STP (Segmentation, Targetting, Positioning). 


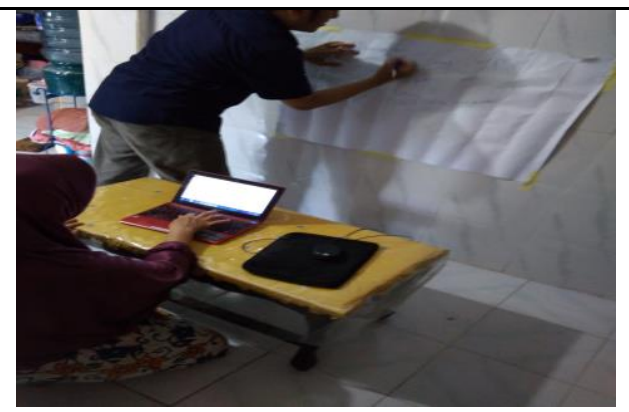

Gambar 6. Pelatihan Pembuatan Konsep Pemasaran

Tabel 2. Hasil Pelatihan Marketing Mix

\begin{tabular}{|lcll|}
\hline Produk & Price & \multicolumn{1}{c}{ Place } & \multicolumn{1}{c|}{ Promotion } \\
\hline Ukuran & $25.000-$ & $\begin{array}{l}\text { Kenngunan } \\
\text { Kirim keluar kota media } \\
\text { dan toko oleh-oleh }\end{array}$ & $\begin{array}{l}\text { social dan } \\
\text { iklan, website, } \\
\text { kerjasama } \\
\text { dengan toko } \\
\text { oleh-oleh }\end{array}$ \\
\hline Ukuran & $18.000-$ & $\begin{array}{l}\text { Toko oleh-oleh } \\
\text { sekitar Gresik }\end{array}$ & $\begin{array}{l}\text { Kerjasama } \\
\text { dengan toko } \\
\text { oleh-oleh }\end{array}$ \\
\hline
\end{tabular}

Tabel 3. Penentuan STP

\begin{tabular}{|lcccl|}
\hline $\begin{array}{l}\text { Ukuran } \\
\text { Produk }\end{array}$ & Price & $\begin{array}{c}\text { Segm } \\
\text { entati } \\
\text { on }\end{array}$ & Targetting & $\begin{array}{c}\text { Positio } \\
\text { ning }\end{array}$ \\
\hline Standar & $\begin{array}{c}25.000- \\
30.000\end{array}$ & $\begin{array}{l}\text { Orang } \\
\text { dewasa }\end{array}$ & $\begin{array}{l}\text { 20 Ikat pudak/ } \\
\text { hari (per ikat 10 } \\
\text { buah pudak) }\end{array}$ & $\begin{array}{l}\text { Isi lebih } \\
\text { padat, } \\
100 \% \\
\text { gula asli }\end{array}$ \\
\hline Kecil & $18.000-$ & $\begin{array}{l}\text { Anak- } \\
\text { anak }\end{array}$ & $\begin{array}{l}\text { 10 Ikat pudak } \\
\text { /hari (per ikat } \\
\text { 10 buah pudak) }\end{array}$ & $\begin{array}{l}\text { Isi lebih } \\
\text { padat, } \\
100 \% \\
\text { gula asli }\end{array}$ \\
\hline
\end{tabular}

\section{Hasil Pelatihan Manajemen Mutu}

Pelatihan manajemen mutu dilakukan dengan dua kegiatan yaitu pelatihan produksi yang bersih dengan menggunakan alat tambahan seperti masker, sarung tangan, dan pengecekan alat produksi yang bersih sebelum dilakukan produksi. Selain itu juga dibuatkan aturan atau prosedur produksi yang bersih di tiap tahap proses produksi.

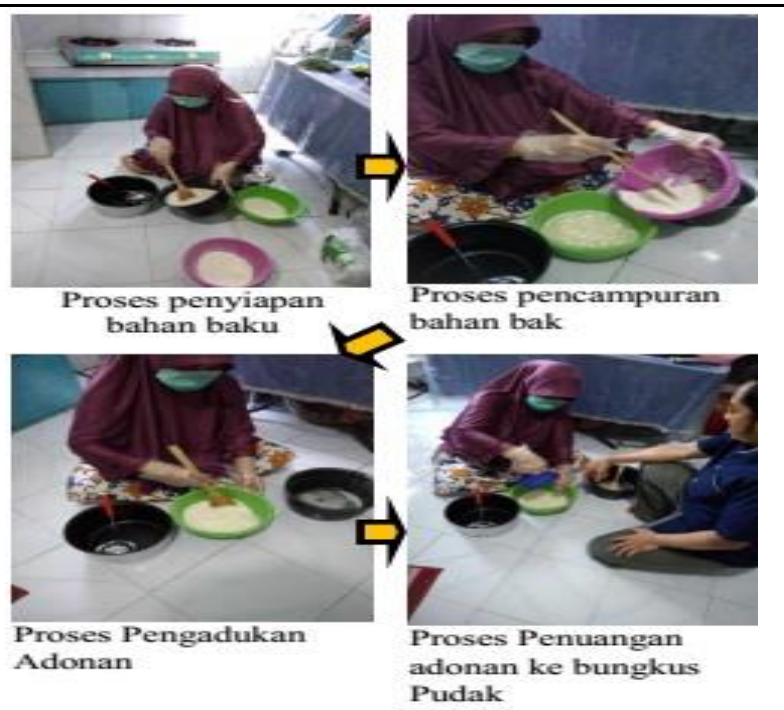

Gambar 7. Pelatihan peningkatan mutu kebersihan pada proses Produksi

Pada pelatihan tersebut mitra dilatih menggunakan masker dan sarung tangan agar terbisa dalam penggunaannya sehingga produk lebih bersih dan higienis. Selain itu juga dilatih pengecekan kebersihan alat produksi sebelum digunakan.

Tabel 4. Hasil Pelatihan Pembuatan SOP (Standart Operation Prosedure) Pada Proses Produksi yang Bersih

\begin{tabular}{|c|l|l|}
\hline No & \multicolumn{1}{|c|}{ Aktivitas } & \multicolumn{1}{c|}{ SOP } \\
\hline 1 & Penyiapan bahan baku & $\begin{array}{l}\text { - Pengecekan alat sebelum } \\
\text { digunakan. } \\
- \text { Membersihkan peralatan } \\
\text { sebelum digunakan }\end{array}$ \\
\hline 2 & $\begin{array}{l}\text { Pencampuran bahan } \\
\text { baku }\end{array}$ & $\begin{array}{l}\text { - Menggunakan masker } \\
- \text { Menggunakan sarung } \\
\text { tangan }\end{array}$ \\
\hline 3 & Pengadukan adonan & $\begin{array}{l}\text { - Menggunakan masker } \\
- \text { Menggunakan sarung } \\
\text { tangan }\end{array}$ \\
\hline 4 & $\begin{array}{l}\text { Proses Penuangan } \\
\text { adonan ke bungkus }\end{array}$ & $\begin{array}{l}\text { - Menggunakan masker } \\
- \text { Menggunakan sarung } \\
\text { tangan }\end{array}$ \\
\hline 5 & Proses pengkukusan & $\begin{array}{l}- \text { Pengecekan kebersihan } \\
\text { alat kukus } \\
- \text { Membersihkan alat kukus }\end{array}$ \\
\hline
\end{tabular}

\section{KESIMPULAN}

Berdasarkan hasil kegiatan yang telah dilakukan dapat disimpulkan penggunaan peralatan mesin pengaduk atau penerapan TTG dapat

$$
\text { Teknologi Tepat Guna }
$$


meningkatkan produktivitas produk. Penerapan variasi produk diharapkan dapat membuat konsumen memiliki beberapa pilihan produk. Pembuatan konsep marketing mix dan penetuan segmentasi, target dan positioning akan memudahkan dalam merancang strategi pemasaran produk. Penerapan manajemen mutu dengan membuat standar operation procedure pada proses produksi akan meningkatkan mutu produk dalam hal kebersihan yang berdampak pada peningkatan higienis produk.

\section{UCAPAN TERIMA KASIH}

Setelah selesainya kegiatan ini maka kami ucapkan terima kasih kepada :

1. Ketua LPPM Universitas Wijaya Putra Surabaya atas dukungan dana untuk kegiatan.

2. Kepada Dekan Fakultas Teknik Universitas Wijaya Putra Surabaya atas dukungannya.

3. Kepada Kaprodi Teknik Industri Universitas Wijaya Putra Surabaya atas dukungannya.

4. Kepada semua rekan Dosen Fakultas Teknik Universitas Wijaya Putra Surabaya atas dukungannya.

\section{REFERENSI}

Kotler \& Keller. (2009). Manajemen Pemasaran. Jilid I Edisi Ke 13 Jakarta: Erlangga.

Moniharapon, S., Oroh, Sem G., \& Ie, Herlin (2015). Penerapan Strategi Promosi Pada Pemasaran Produk Federal Parts CV. Kanaka Jaya Manado, Jurnal EMBA, Vol.3 No.2 Juni 2015, Hal. 650-659.
Muhi Hanapiah A. (2009). Teknologi Tepat Guna (TTG) Dalam Perspektif Pemberdayaan Masyarakat, Institut Pemerintahan Dalam Negeri (IPDN), Jatinangor, alimuhi.staff.ipdn.ac.id/wpcontent/.../01/TTG-dan-Pemberdayaan-

Masyarakat1.pdf.

Nurmianto Eko. (2018). Pentingnya Ergonomi Teknologi Tepat Guna Di Bidang Industri, http://tbmkopel.or.id, diakses 20 Agustus 2018, http://tbmkopel.or.id/2018/01/06/ekonurmiantopentingnya-ergonomi teknologi-tepat-guna-dibidang-industri/.

Selang A.D Christian. (2013). Bauran Pemasaran (Marketing Mix) Pengaruhnya Terhadap Loyalitas Konsumen Pada Fresh Mart Bahu Mall Manado, Jurnal EMBA 71 Vol.1 No.3, Juni 2013, Hal. 71-80.

Slamet, Soemirat Juli (1994). Kesehatan Lingkungan.Yogyakarta: Gajah Mada University Pres.

Sriwidadi Teguh. (2001). Manajemen Mutu Terpadu, Journal The WINNERS, Vol. 2 No. 2, September 2001: 107-115.

Tjiptono Fandy (2008). Strategi Pemasaran, Edisi 3, ANDI: Yogyakarta.

Wardana Rafida, Hubeis Musa, \& Kadarisman Darwin. (2007). Penerapan Sistem Manajemen Mutu dalam Meningkatkan Kinerja Usaha UKM (Kasus di PT Sapukurata Kharisma), Jurnal MPI Vol. 2 No. 2. September 2007. 